\title{
Nutrient profiling of traditionally sun-dried Acetes
}

\author{
A. K. BALANGE, K. A. MARTIN XAVIER, SANATH KUMAR, B. B. NAYAK, \\ G.VENKATESHWARLU AND S. S. SHITOLE \\ ICAR-Central Institute of Fisheries Education, Versova, Andheri (W), Mumbai - 400 061, Maharashtra, India \\ e-mail: amjadbalange@cife.edu.in
}

\begin{abstract}
An attempt was made to study the nutrient profile of traditionally sun-dried Acetes with respect to its proximate composition, amino acids, fatty acids, minerals and heavy metals. From the results, it was found that dried Acetes contained $19.00 \pm 0.70 \%$ moisture, $48.29 \pm 0.64 \%$ crude protein, $16.05 \pm 0.52 \%$ ash and $3.62 \pm 0.09 \%$ crude fat. Biopolymer content in dried Acetes showed $10 \%$ chitin. Amino acid profile of dried Acetes confirmed that it could serve as a significant source of essential amino acids. Fatty acid profile revealed 9, 12-otadecadieonic acid (17.08\%), docosahexaenoic acid (DHA) (15.69\%), eicosapentaenoic acid (EPA) $(13.45 \%)$ and docosanoic acid (11.75\%) as the major fatty acids. Mineral profiling indicated the presence of P, Ca, K, Mg, Na and $\mathrm{Fe}$. Heavy metal analysis indicated the presence of $\mathrm{Cd}, \mathrm{Cu}, \mathrm{Pb}$ and $\mathrm{Zn}$. However, harmful metals like cadmium and lead were found to be low. From microbiological quality analysis of dried Acetes, the total plate count and faecal coliforms count were found to be $4.1 \times 10^{3} \mathrm{cfu} \mathrm{g}^{-1}$ and $35 \mathrm{MPN}$ per $100 \mathrm{ml}$, respectively while Staphylococcus aureus colonies were not detected. Results of the study indicated that dried Acetes was not processed properly and hygienically as revealed by its content of high moisture and faecal coliforms, respectively. Further, based on proximate composition, amino acids, fatty acids and mineral profile, it can be concluded that dried Acetes can be a good source of health beneficial nutrients.
\end{abstract}

Keywords: Acetes, Amino acids, Biopolymer, Fatty acids, Microbial quality, Minerals, Nutrient profiling

Overfishing, together with climate change, is altering the kind and amount of fish found on the Indian coast. Several species of fish and shellfish which were considered as low cost trash species and discarded previously, are now fetching more price due to the decline in the catch of commercial species from the wild. This emphasises the need to give proper importance to the low cost species for adequate value realisation through proper processing under hygienic conditions. The non-penaeid shrimp Acetes spp. that constitutes about $20 \%$ of the total marine shrimp landings of India is one such group gaining importance. It is popularly known as "paste shrimp" and belongs to the family Sergestidae. It is widely distributed in different parts of the world and is found along the coast of many countries bordering the Indian Ocean. In India, most of this shrimp is landed along the north-west coast in the states of Gujarat and Maharashtra where it is locally known as 'jawla'. It is small-sized, growing to a maximum size of $40 \mathrm{~mm}$, weighing $0.2-0.5 \mathrm{~g}$ and highly perishable, spoiling quickly due to autolysis by proteolytic enzymes. Most of the Acetes landed is sold to the fish meal manufacturers at a very low price. Only a small quantity of fresh Acetes is dried in the landing centers of Gujarat and Maharashtra. But due to unhygienic conditions during drying, the commercially dried Acetes is contaminated with sand and other extraneous matter and has a very high bacterial load. Moreover, during peak landing seasons, there is insufficient space onboard fishing vessels to properly ice and store the Acetes harvested, due to which a lot of quality deterioration takes place before drying. After drying, the product is marketed without proper packaging which further deteriorates the quality of the dried material. Only a small quantity of good quality dried Acetes is packed separately and sent to the markets of Punjab, Haryana and North-eastern states. Dried Acetes has export market in Japan, Sri Lanka and other countries. Inspite of its increasing importance, no work has been carried out on the nutritional aspect of dried Acetes. Attempts have been made to prepare Acetes powder (Mulbagal et al., 1980; Jagushthe, 1989) and to separate flesh from Acetes (Garg et al., 1977; Patil, 2000). Jagushthe (1989) prepared products such as sevu, chakli and noodles using powdered Acetes. Damle et al. (1989) prepared a cooked and dried product namely 'kropukudhang' from fresh whole Acetes. As the ground Acetes meat has a high moisture content and shell portion, Patil (2000) prepared Acetes-fish fingers using ground and pressed Acetes meat and fish meat in a combination of 1:1 ratio. Zynudheen et al. (2004) investigated the quality of fresh and dried Acetes with respect to its proximate composition. However, there are no studies on the complete nutrient profiling of traditionally sun-dried Acetes. Hence the present study attempted complete nutrient profiling of traditionally sun-dried Acetes which can be useful for developing new ready to eat products from Acetes. 
For the experiment, traditionally sun-dried Acetes was procured from the commercial drying site of Alibuag, Raigad District, Maharashtra, India. The samples (500 g each) were packed in high density polyethylene pouches and brought to the fish processing laboratory within $3 \mathrm{~h}$. The sun-dried Acetes was then used for analyses of proximate composition, nutrient profile, chitin content, microbial load and heavy metal content.

Chemicals and media for the study viz., sodium chloride, trichloroacetic acid, anhydrous sodium sulphate, potassium chloride, sodium hydroxide, total plate count agar, chloroform, hydrochloric acid, n-heptane, sodium bicarbonate, potassium iodide and sodium thiosulphate were procured from Merck (Mumbai, India) while boron trifluoride was from Merck (Schuchardt OHG, Hohenbrunn, Germany). All chemicals were of analytical grade.

Moisture, crude protein and ash content were determined according to AOAC (1995) and crude fat was determined as per Folch et al. (1957). The microbial quality of dried Acetes was analysed with respect to total plate count, Staphylococcus aureus count and faecal coliforms as per the standard methods (BIS, 2011). Faecal coliforms and Staphylococcus aureus count was determined by MPN method. For nutrient profiling, minerals were determined employing Inductively Coupled Plasma Atomic Emission Spectrometer (ICP-AES) (Model Thermo Electron IRIS INTREPID II XSP DUO, Germany). For this, the sample was digested in a microwave digestor (Milestone, Shelton, Italy), digested sample was aspirated into the flame and the corresponding absorption of the characteristic radiation by each element was recorded. Values were expressed as percentage of whole dried Acetes samples. Further, total amino acid composition was determined following the method of Ishida et al. (1981) using a Shimadzu chromatograph LC-10AT vp high performance liquid chromatograph (HPLC) equipped with an ion exchange column, quaternary pump, a $20 \mu \mathrm{l}$ injection valve and a fluorescence detector. Mobile phase A contained sodium citrate $\left(13.31 \mathrm{~g} \mathrm{l}^{-1}\right)$ and ethanol $\left(70 \mathrm{ml} \mathrm{l}^{-1}\right)(\mathrm{pH} \mathrm{3.5})$ and $\mathrm{B}$ had sodium citrate and $4 \mathrm{~N} \mathrm{NaOH}(\mathrm{pH} 9.8)$. The flow rate was constant at $0.4 \mathrm{ml} \mathrm{min}-1$ and the column temperature was set at $60^{\circ} \mathrm{C}$. The fluorescence excitation and emission wavelengths were 340 and $450 \mathrm{~nm}$, respectively. Samples were hydrolysed in $6 \mathrm{~N} \mathrm{HCl}$ in evacuated sealed tubes at $110^{\circ} \mathrm{C}$ for $24 \mathrm{~h}$. After derivatisation by O-phthalaldehyde, amino acids were identified and quantified by comparison of their retention times with those of standards (Sigma). The results were expressed in terms of per 1000 residues.

Chitin content was estimated as per AOAC (1975). Acetes sample $(2 \mathrm{~g})$ was boiled with $5 \%(\mathrm{w} / \mathrm{v}) \mathrm{NaOH}$ at $90^{\circ} \mathrm{C}$ for $30 \mathrm{~min}$. It was filtered through Whatman filter paper and the residue obtained was washed till alkali free. This residue was digested with conc. $\mathrm{H}_{2} \mathrm{SO}_{4}$ and nitrogen content was estimated as per the Kjeldhal distillation method. Chitin content was calculated by multiplying the chitin nitrogen with conversion factor 14.5 and was expressed on whole Acetes basis.

Total lipid was extracted from Acetes by Folch method and the fatty acid methyl ester (FAME) was prepared from the isolated lipids by heating with the methanolic $\mathrm{NaOH}$ first and then with BF3 methanol for esterification. n-heptane $(5 \mathrm{ml})$ was added to recover the methyl esters in organic phase. The mixture was washed with saturated $\mathrm{NaCl}$ solution and two phases were separated using a separating funnel. The upper n-heptane phase was pipetted out and stored in $10 \mathrm{ml}$ all glass vials until further analysis. Fatty acid profile of dried Acetes was determined using a gas chromatography-mass spectrometry (GC-MS) instrument (Model GCMS-QP 2010, Shimadzu, Japan) equipped with a DB-WAX (30 m $0.25 \mathrm{~mm}$ ID; $0.5 \mu \mathrm{m}$ film thicknesses) capillary column (Cromlab, S.A). Helium was used as the carrier gas. Injector and detector temperature was set at $250^{\circ} \mathrm{C}$. Injection was performed in split mode (1:15). The column temperature was programmed initially at $50^{\circ} \mathrm{C}$ for $2 \mathrm{~min}$ and then it was increased at a rate of $10^{\circ} \mathrm{C}$ per min to a final temperature of $230^{\circ} \mathrm{C}$. FAME was separated at constant pressure $(23.1 \mathrm{kPa})$ and fatty acids were identified by comparing the peaks with the mass spectral database.

Data were subjected to analysis of variance. Comparison of means was carried out by Duncan's multiple-range test. Analysis was performed using SPSS package (SPSS 10.0 for Windows, SPSS Inc, Chicago, IL, USA).

Proximate composition analysis revealed moisture, crude protein, crude fat and ash content to be $19.00 \pm 0.70$, $48.29 \pm 0.64, \quad 3.62 \pm 0.09$ and $16.05 \pm 0.52 \%$ respectively (Table 1). Presence of high moisture content indicated improper drying of Acetes. It is recommended to have less than $10 \%$ moisture for a good quality dried products with extended shelf life. Zynudheen et al. (2004) reported moisture content of $10 \%$ in Acetes dried under controlled conditions. It can be seen from the results that protein content of sun-dried Acetes was higher (48.29 $\pm 0.64 \%)$ along with ash $(16.05 \pm 0.52)$ and fat $(3.62 \pm 0.09)$ indicating its nutritive potential as a food.

Biopolymer content in terms of chitin was found to be $10 \%$ in dried Acetes. Chitin is the most abundant natural

Table 1. Proximate composition of sun-dried Acetes

\begin{tabular}{ll}
\hline Constituents & Values on wet basis $\left(\mathrm{g} 100 \mathrm{~g}^{-1}\right)$ \\
\hline Moisture & $19.00 \pm 0.70$ \\
Crude protein & $48.29 \pm 0.64$ \\
Crude fat & $3.62 \pm 0.09$ \\
Ash content & $16.05 \pm 0.52$ \\
Chitin & $10.00 \pm 0.67$ \\
\hline
\end{tabular}


polysaccharide on earth next to cellulose. It acts as protective and supporting compound with several other health benefits. The large sized shrimps are usually consumed after removal of their shell, but Acetes being very small is usually consumed whole thereby helping in intake of this health beneficial chitin by the consumers. The average head and shell waste yield from the shrimp is around $60 \%$ by weight of the whole shrimp (Pal et al., 2014). Zynudheen et al. (2004) reported chitin content of dried Acetes to be $13.00 \pm 0.67 \%$. But in case of prawn waste, its content is around $15-20 \%$ (Gopakumar, 2002). Results of the present study indicated that the chitin content in dried Acetes was slightly less than that reported earlier.

Amino acid profile of traditionally sun-dried Acetes obtained by acid derivitisation following HPLC analysis are given in Table 2. From the results, it can be seen that amino acids such as glutamine, alanine and aspartic acid to be more with 294.07, 160.55 and 134.97 per 1000 residues, respectively in traditionally sun-dried Acetes. Essential amino acids like leucine, lysine and sulphur containing amino acids are also present in good amount i.e., 90.41, 53.66 and 54.85 per 1000 residues, respectively. From these results, it can be confirmed that, in terms of both quantity and quality, Acetes can serve as an important source of essential amino acids and that the sulphur-containing essential amino acids and lysine present in Acetes can supplement the corresponding deficiencies in plant proteins. Eight essential and five non-essential amino acids including glutamine, asparagine, lysine, leucine, arginine, glycine and valine were recorded in abundant qualities in the caridean prawn Macrobrachium vollenhoveni from Ovia River and tropical periwinkle Tympanotonus fuscatus (Ehigiator and Oterai, 2012). Vazquez-Ortiz et al. (1995) reported, free amino acid contents of glycine, alanine

Table 2. Amino acid profile of sun-dried Acetes

\begin{tabular}{ll}
\hline Amino acids & (per 1000 residues) \\
\hline Aspartic acid & 134.97 \\
Theronine & 23.40 \\
Serine & 32.98 \\
Glutamine & 294.07 \\
Proline & 13.93 \\
Glycine & 19.31 \\
Alanine & 160.55 \\
Valine & 35.40 \\
Methionine & 12.12 \\
Isoleucine & 22.94 \\
Leucine & 90.41 \\
Tyrosine & 12.05 \\
Phenylalanine & 18.20 \\
Histidine & 54.85 \\
Lysine & 53.66 \\
Arginine & 30.79 \\
\hline
\end{tabular}

and proline to be higher than those of other amino acids in wild and cultured shrimp species Penaeus vannamei.

Fatty acid profile by GCMS revealed EPA (13.11\%) and DHA (8.19\%) as the major fatty acids in Acetes. From these results, it can be concluded that dried Acetes can be a good source of health beneficial omega-3 fatty acids, i.e., DHA and EPA (Table 3). The principal fatty acids in the marine shrimps, Penaeus brasiliensis, Penaeus schimitti and Xiphopenaeus kroyeri were, reported as C16:0, C20:5 n-3, C22:6 n-3, C18:1 n-9, C18:0, 16:1 n-7, 20:4 n-6 and 18:1 $\mathrm{n}-7$ and in the freshwater prawn Macrobrachium rosenbergii, the major fatty acids found were, C16:0, C20:5 n-3, C18:1 n-9, C18:0, C22:6 n-3, C18:2 n-6, C17:0 and C18:1 n-7 (Bragagnolo and Rodriguez-Amaya, 2001). Fatty acid profile of dried Acetes indicated the presence of most of the fatty acids reported earlier.

Table 3. Fatty acid profile of sun-dried Acetes

\begin{tabular}{|c|c|c|}
\hline Fatty acids & Formula & $\begin{array}{l}\% \text { of total } \\
\text { fatty acids }\end{array}$ \\
\hline Methyl tetradecanoate & $\mathrm{C} 14: 0$ & 5.56 \\
\hline Pentadecanoic acid & $\mathrm{C} 15: 0$ & 0.92 \\
\hline Hexadecanoic acid & $\mathrm{C} 16: 0$ & 32.15 \\
\hline 9- Hexadecenoic acid & $\mathrm{C} 16: 1(\mathrm{n}-7)$ & 14.95 \\
\hline Heptadecanoic acid & $\mathrm{C} 17: 0$ & 1.82 \\
\hline Octadecanoic acid & $\mathrm{C} 18: 0$ & 7.35 \\
\hline 9-Octadecenoic acid & C18:1 (n-9) & 7.82 \\
\hline 9, 12- Octadecadienoic acid & C18:2 (n-6) & 1.56 \\
\hline 9,12,15-Octadecatrienoic acid & $\mathrm{C} 18: 3(\mathrm{n}-3)$ & 0.98 \\
\hline Eicosanoic acid & C20:0 & 0.40 \\
\hline 11- Eicosenoic acid & C20:1 (n-9) & 0.31 \\
\hline $\begin{array}{l}5,8,11,14 \text { - Eicosatetraenoic } \\
\text { acid }\end{array}$ & $\mathrm{C} 20: 4(\mathrm{n}-6)$ & 4.87 \\
\hline $\begin{array}{l}5,8,11,14,17 \text { Eicosapentanoic } \\
\text { acid }\end{array}$ & C20:5 (n-3) & 13.11 \\
\hline $\begin{array}{l}4,7,10,13,16, \\
\text { 19-Docosahexaenoic acid }\end{array}$ & $\mathrm{C} 22: 6(\mathrm{n}-3)$ & 8.19 \\
\hline
\end{tabular}

Mineral profiling (Table 4) showed that traditionally sun-dried Acetes contains P, Ca, K, Mg, Na and Fe. Among these minerals, $\mathrm{Ca}$ and $\mathrm{Na}$ were found in higher proportions, i.e. 4.553 and $3.016 \%$ respectively. Sriket et al. (2007) reported that black tiger shrimp meat had higher contents of minerals than white shrimp meat and $\mathrm{Mg}$ was the dominant mineral in the meat of both the shrimps, followed by $\mathrm{Ca}$ and $\mathrm{Fe}$ at high levels. Ca is essential for hard tissue structure, blood clotting, muscle contraction, nerve transmission, osmoregulation and as a cofactor for enzymatic procession (Lovell, 1989). In the present study, Acetes showed dominancy of $\mathrm{Ca}$ than other minerals.

Heavy metal analysis (Table 5) revealed the presence of cadmium $(\mathrm{Cd})$, copper $(\mathrm{Cu})$, lead $(\mathrm{Pb})$ and zinc $(\mathrm{Zn})$ at 
Table 4. Mineral content of sun-dried Acetes

\begin{tabular}{ll}
\hline Minerals & Quantity $\left(\mathrm{g} 100 \mathrm{~g}^{-1}\right.$ sample $)$ \\
\hline $\mathrm{P}$ & 0.030 \\
$\mathrm{Ca}$ & 4.553 \\
$\mathrm{~K}$ & 0.980 \\
$\mathrm{Mg}$ & 0.924 \\
$\mathrm{Na}$ & 3.016 \\
$\mathrm{Fe}$ & 0.023 \\
\hline
\end{tabular}

Table 5. Heavy metal content of sun-dried Acetes

\begin{tabular}{ll}
\hline Heavy metals & Quantity $(\mathrm{ppm})$ \\
\hline $\mathrm{Cd}$ & 1.42 \\
$\mathrm{Cu}$ & 39.51 \\
$\mathrm{~Pb}$ & 0.47 \\
$\mathrm{Zn}$ & 46.48 \\
\hline
\end{tabular}

$1.42,39.51,0.47$ and 46.48 ppm concentration, respectively. Heavy metal concentration in tissues of shrimp and fish depends upon the food chain or link of food chain. Therefore, these organisms are good indicators of metal accumulation in marine environment. The high concentration of zinc found in the dried Acetes in the present study is indicative of the greater extent of pollution of the water from which it was caught.

Results of microbial analyses showed total plate count (TPC) in dried Acetes as $4.1 \times 10^{3} \mathrm{cfu} \mathrm{g}^{-1}$. Faecal coliforms determined by MPN method was $35 \mathrm{MPN} 100 \mathrm{ml}^{-1}$. Colonies of $S$. aureus were not detected. From these results, it can be concluded that the dried Acetes was not processed hygienically as reflected by the presence of higher number of faecal coliforms. However, proximate composition, amino acids, fatty acids and mineral profiles of dried Acetes indicate that it can be a good source of health beneficial nutrients.

\section{Acknowledgements}

The authors would like to express their sincere thanks to Dr W. S. Lakra, former Director, ICAR-CIFE, Mumbai for the facilities provided to carry out the work.

\section{References}

AOAC 1975. Official methods of analysis, $12^{\text {th }}$ edn. Association of Official Analytical Chemists, Washington DC, USA.

AOAC 1995. Official methods of analysis, $16^{\text {th }}$ edn. Association of Official Analytical Chemists, Washington DC, USA.

BIS 2011. Indian Standard: Drinking water specification, Second Revision (December 2011), Bureau of Indian Standards, IS 10500-1991, New Delhi.

Date of Receipt : : 28.01.2017

Date of Acceptance : 30.06 .2017
Bragagnolo, N. and Rodriguez-Amaya, D. B. 2001. Total lipid, cholesterol and fatty acids of farmed freshwater prawn (Macrobrachium rosenbergii) and wild marine shrimp (Penaeus brasiliensis, Penaeus schimitti, Xiphopenaeus kroyeri). J. Food Compos. Anal., 14(4): 359-369.

Damle, S. P., Garg, D. G., Nimbiar, V. N. and Valsan, A. P. 1989. Non-traditional exotic product from jawala prawns. In: Recent trends in processing low cost fish. Society of Fisheries Technologists (India), Kochi, p. 121-123.

Ehigiator, F. A. R. and Oterai, E. A. 2012. Chemical composition and amino acid profile of a Caridean prawn (Macrobrachium vollenhovenii) from Ovia River and tropical periwinkle (Tympanotonus fuscatus) from Benin River, Edo State, Nigeria. Int. J. Res. Rev. Appl. Sci., 11(1): 162-167.

Folch, J., Lees, M. and Stanley, G. H. S. 1957. A simple method for the isolation and purification of total lipids from animal tissues. J. Biol. Chem., 226: 497-509.

Garg, D. K., Nair, A. L. and Prabhu, P. V. 1977. Protein from Jawla prawn (Acetes spp.) and Squilla (Ortosquilla nepa). Fish. Tech., 14(1): 53-56.

Gopakumar, K. 2002. Textbook of fish processing technology. Indian Council of Agricultural Research, New Delhi, p. 467-483.

Ishida, Y., Fujita, T. and Arai, K. 1981. New detection and separation method for amino acid by high performance liquid chromatography. J. Chromatogr., 204: 143-148.

Jagushthe, 1989. Studies on biology, biochemistry, bacteriology and utilization of Acetes indicus. M. Sc. Thesis, Konkan Krishi Vidyapeeth, $52 \mathrm{pp}$.

Lovell, R. T. 1989. Nutrition and feeding of fish. Van Nostrand Reinhold, New York, 260 pp.

Mulbagal, A. N., Mahajan, S. N. and Ranade, A. M. 1980. Preparation of edible powder from Jawala (Acetes spp.) prawn. Fish. Tech., 1(2): 125-128.

Pal, J., Verma, H., Munka, V., Maurya, S., Roy, D. and Kumar, J. 2014. Biological method of chitin extraction from shrimp waste: an eco-friendly low cost technology and its advanced application. Int. J. Fish. Aquat. Studies, 1(6): 104-107.

Patil, M. V. 2000. Studies on the separation of Acetes meat and shell. M. F. Sc. Thesis, Konkan Krishi Vidyapeeth. 52 pp.

Sriket, P., Benjakul, S., Visessanguan, W. and Kijoongrojana, K. 2007. Comparative studies on chemical composition and thermal properties of black tiger shrimp (Penaeus monodon) and white shrimp (Penaeus vannamei) meats. Food Chem., 103(4): 1199-1207.

Vazquez-Ortiz, F. A., Caire, G., Higuera-Ciapara, I. and Hernandez, G. 1995. High performance liquid chromatographic determination of free amino acids in shrimp. J. Liq. Chromatogr., 18(10): 2059-2068.

Zynudheen, A., Ninan, G., Sen, A. and Badonia, R. 2004. Processing and utilisation of Acetes (Jawla prawn). CIFT Technology Advisory Series, 15: 1-6. 